\title{
Preparing The Subject-Specific Pedagogy using REACT Strategy for Improving Higher-Order Thinking Skills
}

\author{
Eka Indaryani $^{1}$, Dwi Sulisworo ${ }^{2}$, Suparwoto $^{3}$, Moh Toifur $^{4}$ \\ \{eka.indaryani.1993@gmail.com ${ }^{1}$, sulisworo@gmail.com² ${ }^{2}$, suparwoto@uny.ac.id ${ }^{3}$ \} \\ Graduate Program of Ahmad Dahlan University, Jl. Pramuka No. 42, Yogyakarta, Indonesia 1,2,3,4
}

\begin{abstract}
Many teachers have applied cooperative learning in class to achieve learning competencies. This study aims to develop SSP in cooperative learning with the REACT strategy (React (Relating, Experiencing, Applying, Cooperative, Transferring) to physics in tenth-grade students. The experts gave qualitative judgment to verify the SSP before the teacher used it to arrange the learning environment in the classroom. The research design used in this implementation to find out the learning effects was a pretest-posttest controlled group design. The learning competencies measured were on the ability of analysis and synthesis using five essay questions. Scoring used a weighted score for each step in solving the essay problem. The statistical analysis is ANOVA to compare the two groups. The results indicate that learning with REACT strategies had a better impact than conventional learning. The completeness of learning tools is one of the essential factors to achieve competency in learning cooperative learning.
\end{abstract}

Keywords: Cooperative learning, Higher-order thinking skills, ICT in education, Subject-specific pedagogy

\section{Introduction}

Learning is an interactive process between learners with learning media and the environment to achieve the aim of education. The success of achieving the aim of education depends on the learning process involving three components which are the teacher, learning materials and learners and interaction facilities such as methods, learning media, and environment management.

Referring to the curriculum of 2013 (K-13), the education in Indonesia aims to prepare human resources of Indonesia to have life skills as an individual and citizen who is faithful, productive, creative, innovative and effective and able to contribute for the community, the nation, the state, and the world civilization. To achieve the aim, the implementation of the curriculum of 2013 is implemented in learning at school. Learning according to the curriculum of 2013 is competence learning by strengthening the learning process and authentic evaluation to achieve the competencies of attitude, knowledge, and skills.

Physics is science based on facts, the result of thought and experiments conducted by the experts. In physics learning, learner's ability in doing an act and solving a problem is by observing, questioning, collecting data, associating, implementing the concepts and principles to solve the problems towards what is learned, and also communicating the result [1]. The physics learning process should emphasize giving direct learning experiences to develop the 
competencies so that learners are able and understand the nature of physics-based on scientific attitudes to solve the problems faced [2]. Therefore, physics learning emphasizes on giving direct experiences and is learner-centered.

The learning model is a conceptual pattern and framework used by learners to organize learning materials and functions as an effort of giving the teacher guideline in planning and conducting learning [3]. Developing a learning model structurally and systematically in the learning instruments could respond to learners in learning and critical thinking skills. Relating, Experiencing, Applying, Cooperating, Transferring (REACT) in this context is a learning model that can help the teacher in teaching concepts to students; students are engaged to find the concept learned themselves, cooperate, implement the concept in daily life and transfer to the new condition.

Learning the linear motion materials might be exciting, and the learning objectives could be achieved by implementing REACT learning model. Students get opportunities of direct learning experiences both inside and outside the classroom by utilizing computers, smartphones, and internet network so that students could actively participate in the teachinglearning process called e-learning. The utilization of e-learning could give learners learning experiences particularly experience in utilizing technology and information. Besides, from the teacher aspect, e-learning could ease the teacher in controlling student's activities and increase learning interaction between students and the teacher, so the teacher more understands the capability of each student [4-5]. Thus, learning the materials of motions with e-learning could give experiences and utilize technology or learning media. One of the e-learning modes is WhatsApp. WhatsApp is an application designed for distance-learning (e-learning). It is one of the online applications that need an internet network to access. In this context, learning via WhatsApp requires an adequate internet network so that it runs well.

Besides learning models and media, achieving the skills of 21 st-century learning also needs innovation from the packaging of subject matters or well-known as learning instruments. Learning instruments are the packaging of subject matters in the form of comprehensive and educative learning instruments. Learning instruments consist of four essential components which are the syllabus, lesson plans, learner's worksheet, and evaluation instruments [6]. If the teacher could arrange the complete learning instruments and implement learning in the classroom based on the learning instruments arranged, the learning activities in the classroom could become more directed, and the quality of students could also improve [78]. Therefore, learning instruments must be prepared before learning starts so that learning activities become more directed and could achieve the learning objectives.

Developing physics learning instruments by using e-learning platforms such as WhatsApp is an appropriate learning instrument development to be applied following the demand of the curriculum of 2013 and is expected to improve the student's concept comprehension. The learning process in the curriculum of 2013 put learning media as learning facilities on all subjects or integrated into all subjects. Ministry of Education and Culture Republic of Indonesia explained that on the development of the curriculum of 2013, the teacher is expected to observe information and media. Learning media has a strategic role in skills and competencies.

Students tend to be more excited in physics learning that gives knowledge and skills that are relevant to the needs and benefits of daily life. A suitable learning style is by relating learning materials with everyday life experiences, so students get interested and satisfied in learning [9-11]. Thus, the effort to increase student's learning responses in learning could be made by involving student's activities in the learning process, such as cooperative learning, discussion among students and the teacher [12]. One of the factors that significantly influence 
the student's success in learning is the presence of student's responses in learning to understand learning materials. The linear motion materials are related to formula or calculation. Besides critical thinking skills, students also need to respond to learning to increase the concept of comprehension in physics learning. Student's responses in learning can influence how a student study as a trigger that motivates the student to be enthusiastic and severe in the learning activities, so students will be more comfortable to understand the learning materials. Therefore, this research aimed to develop the subject-specific pedagogy for linear motion lessons using the REACT model to improve the students' critical thinking skills.

\section{Literature review}

Learning instruments are a set of media and facilities used by the teacher or students in the learning process so that the learning process runs well, effectively, and efficiently. In physics learning, the teacher arranges physics learning instruments based on the learning objectives so that learning runs well as previously planned, so students are motivated to learn and easy to understand the materials delivered by the teacher. In this research, the learning instruments developed to manage learning were the syllabus, lesson plans, student's worksheets, and evaluation instruments.

The REACT learning model is a learning model that can help the teacher in teaching the concepts to students. Students are encouraged to self-finding of the concepts learned, cooperate, and implement the concepts in daily life and transfer in new condition [13-14]. The phases of the REACT model always involve students. The activities cover activities of relating, experiencing, applying, cooperating, and transferring in the student's learning process $[15,16]$. Students do not quickly get bored, are more motivated to attend learning, and easy to understand the materials they are learning. The learning process also presents the problems they find in daily life, so they can analyze the issues well, easy to relate them to learning, able to apply and utilize it in real life $[11,17]$.

Media is an essential part of the teaching-learning process. The learning process can run effectively if all components of learning support each other to achieve the common objectives. According to [18], the elements of learning are learning objectives, students, teachers, curriculum, learning materials, learning methods, learning facilities (aids/ tools, media), and learning evaluations. Learning activities should involve students to participate and directly engage in learning so that students could master the teaching materials, so the learning achievement is optimum with the use of instant messaging service media of WhatsApp as a learning tool. Quoted from Google Play Store page for WhatsApp, it states that WhatsApp messenger is a free messaging application available for Android and other smartphones that use internet connection such as $4 \mathrm{G}, 3 \mathrm{G}$, EDGE or Wi-Fi to let users send and receive messages, calls, images, videos, documents and voices with friends or family (Google Play Store). On the official website, WhatsApp for Android operation system can be accessed directly on the application or via the play store website.

Students understood the materials if students know what is being communicated and could use the materials or ideas. Communication could be spoken or written and verbal or symbolic. The concept comprehension could be described in three aspects which are translation, interpretation, and extrapolation. 


\section{Methods}

\subsection{Research context}

This research is Research and Development (R\&D) with 4-D models [19]. The phases are defined, design, develop, and disseminate. In this context, disseminate is just giving the product to school. The subject of the research was tenth-grade students of MIA Madrasah Aliyah Al-Fatah Palembang in the academic year of 2018/2019 as part of the limited experiment of the product.

\subsection{Research instruments}

Instruments used in this research were validation sheets of physics learning instruments including syllabus, lesson plan, student's worksheet (student's book), comprehension test of the linear motion, critical thinking skill test, and student's responses in learning. Instrument data collection used validation sheets and questionnaires. Validators consisted of two lecturers, two physics teachers, and two peers.

The data analysis technique used (a) tabulation of all data obtained for each aspect of evaluation item available in the instrument; (b) total of score obtained was converted in the form of qualitative data of five scales as shown in Table 1.

Table 1. Conversion of quantitative and qualitative data.

\begin{tabular}{cccc}
\hline No & Interval & Score & Criteria \\
\hline 1 & $\bar{X}+1,80 S B_{i}<X$ & A & Very Good \\
2 & $\bar{X}+0,60 S B_{i}<X \leq \bar{X}+1,80 S B_{i}$ & B & Good \\
3 & $\bar{X}-0,60 S B_{i}<X \leq \bar{X}+0,60 S B_{i}$ & C & Fair \\
4 & $\bar{X}-1,80 S B_{i}<X \leq \bar{X}-0,60 S B_{i}$ & D & Less Fair \\
5 & $X \leq \bar{X}-1,80 S B_{i}$ & E & Poor \\
\hline
\end{tabular}

The product reliability used PA (Percentage Agreement). The formulation can be seen in Equation 1.

$$
P A=\left\{1-\frac{(A-B)}{(B-A)}\right\} \times 100 \%
$$

where:

$\mathrm{PA}=$ Percentage of Agreement (\%).

$\mathrm{A}=$ Higher validator score.

$\mathrm{B}=$ Lower validator score

If $\mathrm{PA}>75 \%$, then data is reliable.

\subsection{Data analysis}

The data analysis technique in this research used descriptive analysis and research hypothesis test analysis. The descriptive analysis analyzed mean (m), standard deviation (sd), 
modus (mo), and median (m), prior knowledge test (pretest), concept comprehension test (posttest), critical thinking skill and student's learning responses. To test the difference in learning achievement, a hypothesis was made. The test used covariant analysis (Anacova) with three included variables.

Besides anacova test, the difference test analysis of the scoring average of the student's concept comprehension was also done. T-test statistic was used to test the difference in learning achievement. The use of t-test analysis and covariant analysis test techniques required the data to have a normal distribution, homogenous and linear.

After the precondition analysis, those were score distribution normality, variant homogeneity, and linearity test was complete, the hypothesis test was done. The hypothesis testing used a one-way anacova test with three included variables. Anacova is a combination of variant and regression analysis. Anacova hypothesis testing was done by using SPSS 16.0. The two-sample comparative hypothesis could be presented in forms of testing paramer that stated in Equation 2,3.

$$
\begin{aligned}
& \mathrm{H}_{\mathrm{o}}: \mu 1=\mu 2 \\
& \mathrm{H}_{\mathrm{a}}: \mu 1 \pm \mu 2
\end{aligned}
$$

Acceptance or Rejection criteria of $\mathrm{H}_{0}$ in the significance level of 5\% with F-test is that $\mathrm{H}_{0}$ is rejected if $\mathrm{F}_{\text {hitung }}$ is more than $\mathrm{F}_{\mathrm{t} 5 \%}$. Acceptance or rejection of $\mathrm{H}_{0}$ could also be viewed through probability (significance) which is if significance $<0.05$ so $\mathrm{H}_{0}$ is accepted, vice versa. If the probability of significance $<0.05, \mathrm{H}_{0}$ is rejected. Before determining the contribution of pretest result, critical thinking skill and student's learning responses towards the concept comprehension, the t-test was first calculated using equation 4.

$$
B R S=t_{5 \%} \sqrt{\frac{2\left(M K_{d}{ }^{*}\right)}{n}}
$$

where:

$\mathrm{t}_{5 \%}=\mathrm{t}_{\text {table }}$ with significance level of $5 \%$

$\mathrm{n}=$ number of subject

After obtaining the t-test score, further test to determine the contribution of pretest, critical thinking skills and student's learning responses towards the concept comprehension was made.

\section{Result and discussion}

From the analysis done, this research aims to develop physics learning instruments with the REACT model by using WhatsApp in the linear motion subject materials and to describe the product feasibility. The validation result of each component of the learning instruments consisting of the syllabus, lesson plan, student's worksheets and evaluation instruments from expert lecturers, physics teachers, and peers is categorized as very good. It means every component or overall physics learning instrument is feasible to be experimented based on the validators' evaluation. Besides evaluating the learning instruments, validators also 
recommended the improvement of the learning instruments. All good recommendations from validators have been used to improve the learning instruments. Table 2 shows a summary of the learning instrument validation.

\subsection{Product validation}

Table 2 shows the result of the product quality validation.

Table 2. Product quality validation by experts, teachers, and peers.

\begin{tabular}{cccccc}
\hline No & Instrument & Experts & Teachers & Peers & Category \\
\hline 1 & Syllabus & 3.72 & 3.56 & 3.67 & Very good \\
2 & Lesson plan & 3.95 & 3.93 & 3.88 & Very good \\
3 & Student's worksheet & 3.70 & 3.83 & 3.63 & Very good \\
4 & Concept comprehension questions & 3.65 & 3.75 & 3.85 & Very good \\
5 & Critical thinking skill questions & 3.65 & 3.80 & 3.69 & Very good \\
6 & Student's learning response & 3.81 & 3.75 & 3.69 & Very good \\
\hline
\end{tabular}

The validator evaluation is then analyzed to determine the reliability by using the Percentage Agreement (PA) in \% as shown in Table 3.

Table 3. Percentage Agreement (PA).

\begin{tabular}{cccccc}
\hline \multirow{2}{*}{ No } & Instrument & PA (\%) & PA (\%) & PA (\%) & Category \\
& & Expert & Teacher & Peer & Catiable \\
\hline 1 & Syllabus & $97.76 \%$ & $95.57 \%$ & $98.52 \%$ & Reliable \\
2 & Lesson Plan & $96.81 \%$ & $96.56 \%$ & $96.51 \%$ & Reliable \\
3 & Student's worksheet & $89.95 \%$ & $98.15 \%$ & $95.46 \%$ & Reliable \\
4 & Concept comprehension questions & $94.59 \%$ & $97.33 \%$ & $97.43 \%$ & Reliable \\
5 & Critical thinking skill questions & $99.31 \%$ & $98.70 \%$ & $98.67 \%$ & Reliable \\
6 & Student's learning response & $98.29 \%$ & $98.37 \%$ & $96.55 \%$ & Reliable \\
\hline
\end{tabular}

Note: PA > 75\% means Reliable

Table 3 informs the PA (percentage agreement) of each component including syllabus, lesson plans, student's worksheets, and evaluation instruments. It shows that physics learning instruments developed is reliable and feasible to be used in learning.

\subsection{Statistical requirement calculation}

The normality test finds out whether each sample comes from a population that has a normal distribution or not. The normality test in this research used the One-Sample Kolmogorov-Smirnov Test on the SPSS 16 with a significance level of 0.05 . Table 4 informs that the result of the significance score of all variables for both experimental and control classes is> 0.05 which means data of scores of all variables for experimental and control classes come from the normal distribution of the population. 
Table 4. The summary of distribution normality.

\begin{tabular}{cccc}
\hline Variables & $\begin{array}{c}\text { Experimental } \\
\text { group }\end{array}$ & $\begin{array}{c}\text { Control } \\
\text { group }\end{array}$ & Conclusion \\
\hline Pretest & 0.120 & 0.174 & Normal distribution of data \\
Posttest & 0.120 & 0.191 & Normal distribution of data \\
Critical thinking skills & 0.191 & 0.114 & Normal distribution of data \\
Student's learning response & 0.200 & 0.200 & Normal distribution of data \\
\hline
\end{tabular}

Coming from the normal distribution of the population, the homogeneity test was then done. The homogeneity test is to find out whether the variants of the two populations are homogenous or not. The homogeneity test in this research used the variant homogeneity test on SPSS 16. Table 5 shows a summary of the homogeneity test.

Table 5. The summary of variants homogeneity.

\begin{tabular}{cccccc}
\hline & $\begin{array}{c}\text { Levene } \\
\text { Statistic }\end{array}$ & df1 & dt2 & Sig. & Conclusion \\
\hline Pretest & 0.006 & 1 & 48 & 0.941 & homogenous Variant \\
Posttest & 2.184 & 1 & 48 & 0.146 & homogenous Variant \\
Critical thinking skills & 0.027 & 1 & 48 & 0.871 & homogenous Variant \\
$\begin{array}{c}\text { Student's learning } \\
\text { response }\end{array}$ & 0.661 & 1 & 48 & 0.420 & homogenous Variant \\
\hline
\end{tabular}

Table 5 informs that the significance score of the variant homogeneity test for the experimental and control class for the four variables are more than the significance level of 0.05. It means there are no different invariants between experimental and control classes. In other words, they are homogenous.

\subsection{The statistical analysis}

T-test analysis was used to find out the significant difference in the result of the posttest measuring the concept comprehension between the experimental and control classes. T-test analysis using SPSS 16.0. Table 6 shows the result of the t-test.

Table 6. The result of t-test analysis.

\begin{tabular}{ccccccc}
\hline Class & $\mathrm{N}$ & Mean & $t_{\text {-calculated }}$ & Df & $\begin{array}{c}\text { sig. } \\
\text { (2-tailed) }\end{array}$ & A \\
\hline Experimental & 25 & 88 & 5.24 & 47.99 & 0.000 & 0.05 \\
Control & 25 & 78 & 5.24 & 46.04 & 0.000 & \\
\hline
\end{tabular}

Table 6 shows the result of the t-test analysis which is 5.24 with sig. (2-tailed) 0.000 . Since sig. less than 0.05 , so it can be concluded that there is a significant difference in the result of the posttest measuring the concept comprehension between the experimental and control classes. By using three variables covariant analysis technique, the result informs that by controlling the result of pretest, critical thinking skill and student's learning response, there is a significant difference in learning score average between experimental and control classes. As shown by the determination coefficient of 3.398 and the difference in posttest average score of the experimental class is higher than the control class. Table 7 informs that 
Fcalculated is 9.07 and the Ftable for significance level $(\alpha)$ of 0.05 is $4.03 . F_{\text {calculated }}$ higher than Ftable and sig. is less than $\alpha$ or 0.05 , then $\mathrm{H} 0$ is rejected. It can be concluded that after being controlled with covariates of pretest result, critical thinking skill, and student's learning response, there is a significant difference in posttest scores measuring the concept comprehension between experimental and control classes.

Table 7. The summary of the result of anacova analysis.

\begin{tabular}{ccccccc}
\hline Number of & \multicolumn{5}{c}{ Residual } & \multirow{2}{*}{ Note } \\
\cline { 2 - 5 } variety & $D_{b}$ & $J_{K}$ & $R J_{K}$ & $F_{\text {hitung }}$ & $F_{\text {Tabel }}$ & \\
\hline Between A & 1 & 724.92 & 724.92 & & & \multirow{2}{*}{$F_{h i t}>F_{15 \%}$} \\
In & 46 & 149993.3624 & 88.11 & 9.07 & 4.03 & \\
Total & 47 & 3677.7 & & & & \\
\hline
\end{tabular}

The contribution of each variable is to find out the predictor contribution of each independent variable. There are two types of contributions which are the effective and relative contribution. Table 8 shows a summary of the relative and effective contribution of each independent variable towards dependent variables.

Table 8. The relative and effective contribution of each covariate.

\begin{tabular}{ccc}
\hline Covariate & $\begin{array}{c}\text { Relative } \\
\text { Contribution }(\%)\end{array}$ & $\begin{array}{c}\text { Effective } \\
\text { Contribution }(\%)\end{array}$ \\
\hline Prior knowledge & 7 & 3 \\
Critical thinking skill & 44 & 18 \\
Student's learning response & 49 & 19 \\
\hline Total & 100 & 30 \\
\hline
\end{tabular}

Table 8 informs that the most significant contribution to the concept comprehension is from the student's learning responses. The three covariates contribute $30 \%$ towards the concept of comprehension.

\section{Conclusion}

This research developed a product of physics learning instruments with the REACT model by using WhatsApp on the Linear Motions lesson. The components of the learning instruments developed are the syllabus, lesson plans, student's worksheets, and evaluation instruments. Based on the validation done by expert lecturers, physics teachers, and peers, the instruments are very good, valid and reliable, so it is feasible to use the instruments in physics learning. The valid and reliable product was then implemented in learning in the tenth grade MIA Madrasah Aliyah Al-Fatah Palembang and was observed to find out the influence. There is a significant influence of the implementation of the learning instruments on the linear motion materials towards student's concept comprehension. The covariates explain the concept comprehension. The development of the learning instruments covering critical thinking skills and student's learning responses give a significant influence on the concept comprehension.

Acknowledgments. This research is funded by the Ministry of Research, Technology, and Higher Education of Republic Indonesia under the Postgraduate of Physics Education Research Grant for the year 2019. 


\section{References}

[1] Argaw, A. S., Haile, B. B., Ayalew, B. T., Kuma, S. G.: The effect of problem based learning (PBL) instruction on students' motivation and problem solving skills of physics. EURASIA Journal of Mathematics Science and Technology Education. Vol. 13, pp. 857-871 (2017)

[2] Fadila, N. U., Suparwoto: Keterlaksanaan Pembelajaran Fisika Implementasi Kurikulum 2013 Berdasarkan Latar Belakang Akademik Guru. Jurnal Inovasi pendidikan IPA. Vol. 2, pp. 164-169 (2016)

[3] Pedaste, M., Mäeots, M., Siiman, L. A., De Jong, T., Van Riesen, S. A., Kamp, E. T., Manoli, C. C., Zacharia, Z. C., Tsourlidaki, E.: Phases of inquiry-based learning: Definitions and the inquiry cycle. Educational research review. Vol. 14, pp. 47-61 (2015).

[4] Efendi, A.: E-leaning Berbasis Schoology- Ditinjau dari Motivasi dan Hasil belajar Siswa SMK. Elinvo. pp. 49-56 (2017)

[5] Sulisworo, D.: Conceptual model identification of personal learning environment. In International Joint Seminar on School Administration and Multicultural Society. pp. 30-35 (2014)

[6] Hartati, T., Sudarya, Y., Suratno, T., \& Mulyasari, E.: Peragkat pembelajara,. Bandung: Universitas Pendidikan Indonesia (2009)

[7] Purwati, E.: Implementasi Penggunaan Perangkat Pembelajaran Tematik Integratif untuk Menanamkan. Jurnal Pendidikan dan Pembelajaran Dasar. Vol. 4, pp. 363-385 (2016)

[8] Oliver, R. M., Wehby, J. H., \& Reschly, D. J.: Teacher classroom management practices: Effects on disruptive or aggressive student behavior. Campbell Systematic Reviews, 7(1). pp. 1-55 (2011)

[9] Asrizal, A., Amran, A., Ananda, A., \& Festiyed, F.: Effectiveness of Adaptive Contextual Learning Model of Integrated Science by Integrating Digital Age Literacy on Grade VIII Students. In IOP Conference Series: Materials Science and Engineering Vol. 335, No. 1. IOP Publishing. p. 012067 (2018)

[10] Usmeldi, U.: The Development of Research-based Physics Learning Model with Scientific Approach to Develop Students' Scientific Processing Skill. Jurnal Pendidikan IPA Indonesia, vol. 5 ch. 1. pp. 134-139 (2016)

[11] Hwang, G. J., Chiu, L. Y., Chen, C. H.: A contextual game-based learning approach to improving students' inquiry-based learning performance in social studies courses. Computers \& Education. Vol. 81. pp. 13-25 (2015)

[12] Sulisworo, D., Agustin, S. P., Sudarmiyati, E.: Cooperative-blended learning using Moodle as an open source learning platform. International Journal of Technology Enhanced Learning, vol. 8. Ch. 2. pp. 187-198 (2016)

[13] Ismayana, S. N., Subiki, Harijanto A.: Penerapan Model Pembelajaran REACT terhadap Motivasi dan Hasil Belajar dalam Pembelajaran Fisika di SMA. Jurnal Pendidikan Fisika. Vol. 4, pp. 23-24 (2015)

[14] Husna, E.: Penerapan Strategi REACT Dalam Meningkatkan Kemampuan Pemahaman Konsep Matematika Siswa Kelas X SMAN 1 Batang Anai, Jurnal Pendidikan Matematika, Vol. 3, pp. 1-2 (2014)

[15] Amirudin, D., Kusdiwelirawan, A., Soenarto, Y.: Effect of Task Through Test Rankings Based Learning Model REACT to the Achievement of Physics. Omega: Jurnal Fisika dan Pendidikan Fisika. Vol. 3, pp. 31-31 (2017)

[16] Jelatu, S.: Effect of GeoGebra-Aided REACT Strategy on Understanding of Geometry Concepts. International Journal of Instruction. Vol. 11, pp. 325-336 (2018)

[17] Muzdalifa, N.: Penerapan Pendekatan Kontekstual Berbasis REACT Untuk Meningkatkan Hasil Belajar Fisika Pada Siswa Kelas X SMA Negeri 8 Palu. Jurnal Pendidikan Fisika Tadulako (JPFT). Vol. 1 (2013)

[18] Breed, B.: Applying the Elements of Cooperative Learning: Reported Influence on Self-directed Learning and View of Cooperative Learning. Journal of Communication. Vol. 7, pp. 1-12 (2016)

[19] Borg, W., \& Gall, J.: Educational Research 4th edition, Longman Inc, Newyork (2003) 